\title{
Cytogenetical Investigations in Musaceae IV. Cytomorphology of an interspecific triploid hybrid of Musa acuminata Colla. $\times$ M. rubra Wall. ${ }^{1}$
}

\author{
P. K. Agarwal \\ Fruit Breeding Laboratory II, Indian Institute of Horticultural Research (ICAR), \\ Hessaraghatta Lake Post, Bangalore-560 089, India
}

Accepted September 17, 1987

Musa belongs to the family Musaceae, which has two genera and 31-36 species (Simmonds 1966). These species are used as vegetables, fruits, ornamentals and for extracting fiber. Interspecific hybridization has played a major role in the evolution of present day banana. A large number of diploid and triploid cultivars of banana have originated as a result of natural hybridization between Musa acuminata and $M$. balbisiana. However, except for a few reports on interspecific hybridization in banana (Bernardo 1957) no attempt has been made so far to produce artificial interspecific hybrids in $M u s a$ and to study their cytological behaviour to understand species relationship. Investigations were, therefore, conducted to raise interspecific hybrids of Musa and study these cytomorphologically. The present article describes cytomorphology of triploid interspecific hybrids obtained from cross $M$. acuminata $\times M$. rubra.

\section{Material and methods}

The material for present investigations included two species of Musa viz. M. acuminata Colla. and $M$. rubra Wall. Suckers of these species were collected from Banana Research Station, Aduthurai and grown at IIHR Bangalore. For hybridization, flowers in the first hand of $M$. acuminata were emasculated one day before opening, bagged and were pollinated next morning with freshly collected pollen from $M$. rubra and again bagged with cloth bag. Same way all the female flowers in subsequent hands were emasculated, pollinated and bagged. Crossed fruits were allowed to mature and ripen on the plant. Seeds were extracted from these fruits and put for germination in saw dust, inside a mist chamber, soon after harvest. Seedlings were later transplanted to field and grown at a spacing of $2.5 \mathrm{M} \times 2.5 \mathrm{M}$. Observations were taken on various vegetative and fruit characters of parents and their hybrids.

For cytological studies, anthers from young male flower buds were fixed at appropriate time, in 1:3 acetic alcohol solution fortified with saturated aqueous solution of ferric chloride, for $24 \mathrm{hrs}$ at $15^{\circ} \mathrm{C}$ and later transferred to $70 \%$ ethyl alcohol and stored at $5^{\circ} \mathrm{C}$ till use. Squash preparations were made using $2 \%$ acetocarmine solution. Pollen fertility was determined by stainability in acetocarmine solution. Photomicrographs were taken from temporary slides.

\section{Observations}

\section{Morphology:}

Out of fifty hybrids obtained from cross $M$. acuminata $(2 \mathrm{n}=22)$ and $M$. rubra $(2 \mathrm{n}=22)$, forty two were triploids $(2 n=33)$ and rest were higher polyploids. Various morphological features of parents and their hybrids have been described in Table 1. The two species differ strikingly in their growth habit; the underground part is corm (without any horizontal growth) 

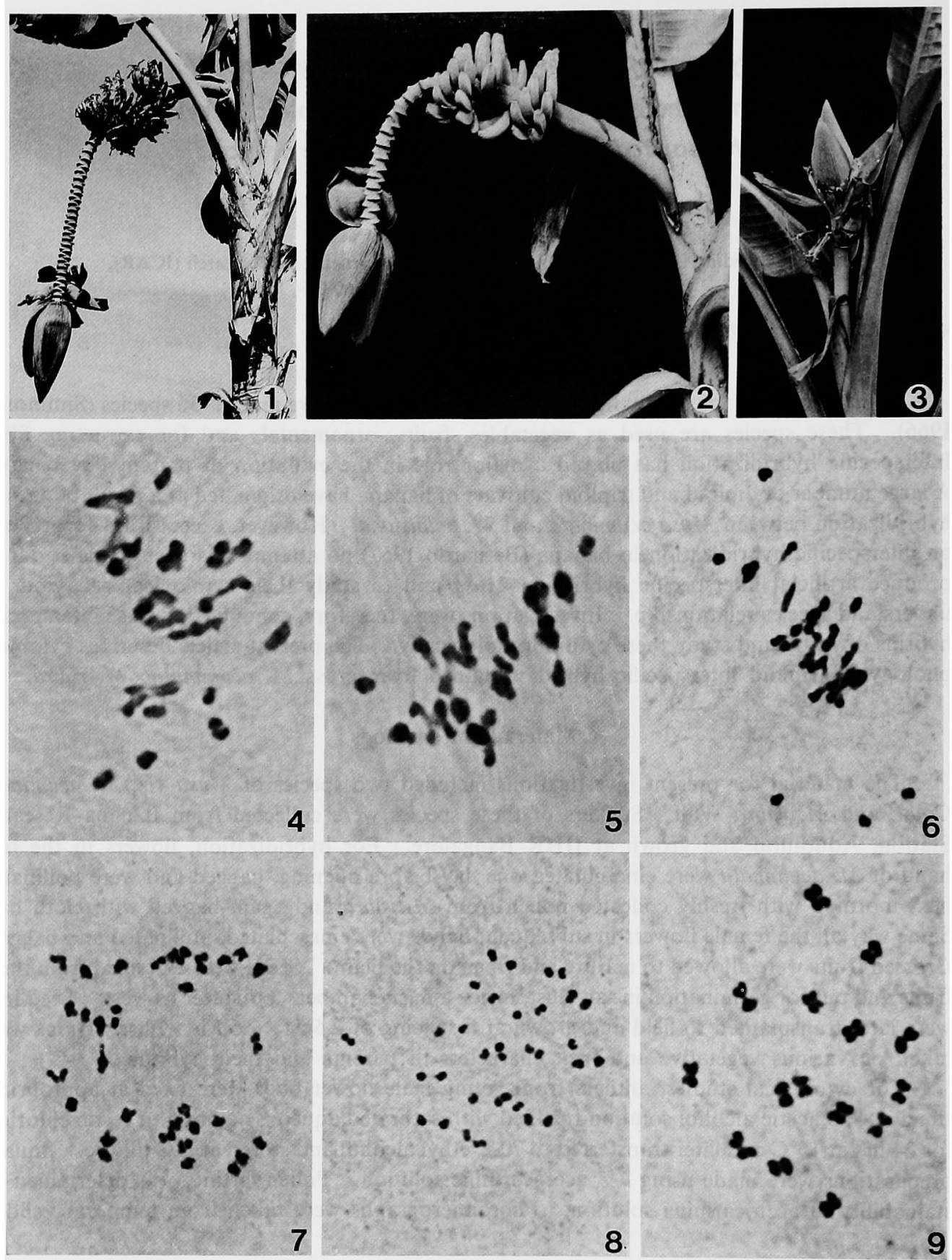

Fig. 1. M. acuminata showing pendulous orientation of females inflorescence.

Fig. 2. M. acuminata $\times M$. rubra hybrid showing horizontal orientation of female inflorescence.

Fig. 3. M. rubra showing upright orientation of female inflorescence.

Fig. 4-9. M. acuminata $\times M$. rubra meiosis. $4, \mathrm{PMC}$ at $\mathrm{M}_{1}$ showing $11_{\mathrm{II}}, 3_{\mathrm{III}}$ and $5_{\mathrm{I}} . \times 1300$. 5 , PMC at $M_{1}$ showing $12_{\mathrm{II}}, 2_{\mathrm{III}}$ and $3_{\mathrm{I}} . \quad \times 1300 . \quad 6, \mathrm{PMC}$ at $\mathrm{M}_{1}$ showing 5 univalents. $\times 1000$. $7, \mathrm{PMC}$ at $\mathrm{A}_{1}$ showing a lagging bivalent. $\times 1000.8, \mathrm{PMC}$ at $\mathrm{A}_{1}$ showing 33 chromosomes. $\times 1000.9, \mathrm{PMC}$ at $\mathrm{M}_{2}$ showing 15 chromosomes. $\times 1300$. 
in $M$. acuminata, rhizome (having lateral growth) in $M$. rubra and corm in the hybrid. $M$. rubra plants are shorter in height as compared to $M$. acuminata, the hybrid is of intermediate height. The angle of female inflorescence, which is pendulous in $M$. acuminata (Fig. 1), vertically up in $M$. rubra (Fig. 3) is horizontal in the hybrid (Fig. 2). Most of the other characters in hybrid are intermediate to the parents. The quantity of pollen produced is very less in $M$. acuminata but more in $M$. rubra, however, in hybrids, pollen quantity varies from plant to plant but fertility is very poor.

Table 1. Morphological characters of Musa acuminata, Musa rubra and their triploid hybrid $M$. acuminata $\times M$. rubra

\begin{tabular}{|c|c|c|c|c|}
\hline Sl. no. & Characters & M. acuminata & M. rubra & $\begin{array}{l}\text { M. acuminata } \times \\
\text { M. rubra triploid }\end{array}$ \\
\hline 1 & Plant height & $1.86 \mathrm{M}$ & $0.9 \mathrm{M}$ & $1.45 \mathrm{M}$ \\
\hline 2 & Leaf length/width ratio & 2.26 & 2.56 & 2.00 \\
\hline 3 & $\begin{array}{l}\text { Angle of female } \\
\text { inflorescence }\end{array}$ & Pendulous & vertically up & horizontal \\
\hline 4 & No. of stomata/unit area & $41-45$ & $41-45$ & 42 \\
\hline 5 & $\begin{array}{l}\text { Length of stomatal } \\
\text { aperture }\end{array}$ & $22.5 \mu$ & $22.5 \mu$ & $25 \mu$ \\
\hline \multirow[t]{2}{*}{6} & $\begin{array}{l}\text { Width of stomatal } \\
\text { aperture }\end{array}$ & $12.5 \mu$ & $13.75 \mu$ & $12.5 \mu$ \\
\hline & Female flowers & & & \\
\hline 7 & Bract colour & dull purple & bright crimson & bright crimson \\
\hline 8 & Length of female flowers & $9.0 \mathrm{~cm}$ & $6.0 \mathrm{~cm}$ & $8.5 \mathrm{~cm}$ \\
\hline 9 & Length of fused petal & $5 \mathrm{~cm}$ & $2.5 \mathrm{~cm}$ & $3 \mathrm{~cm}$ \\
\hline 10 & Length of free petal & $2.6 \mathrm{~cm}$ & $1.3 \mathrm{~cm}$ & $2.5 \mathrm{~cm}$ \\
\hline 11 & Length of stigma & $0.5 \mathrm{~cm}$ & $0.3 \mathrm{~cm}$ & $0.5 \mathrm{~cm}$ \\
\hline 12 & Length of style & $3.5 \mathrm{~cm}$ & $2.5 \mathrm{~cm}$ & $3.5 \mathrm{~cm}$ \\
\hline 13 & Length of ovary & $5.0 \mathrm{~cm}$ & $3.0 \mathrm{~cm}$ & $4.4 \mathrm{~cm}$ \\
\hline 14 & No. of locules & 3 & 3 & 3 \\
\hline 15 & No. of ovules/locule & 2 & 2 & 2 \\
\hline \multirow[t]{2}{*}{16} & No. of staminodes & 5 & 3 & 5 \\
\hline & Male flowers & & & \\
\hline 17 & Length of male flowers & $4.7 \mathrm{~cm}$ & $3.6 \mathrm{~cm}$ & $6.0 \mathrm{~cm}$ \\
\hline 18 & Length of fused petal & $4.7 \mathrm{~cm}$ & $2.7 \mathrm{~cm}$ & $5.0 \mathrm{~cm}$ \\
\hline 19 & Length of free petal & $2.5 \mathrm{~cm}$ & $1.1 \mathrm{~cm}$ & $2.7 \mathrm{~cm}$ \\
\hline 20 & Length of stamens & $4.7 \mathrm{~cm}$ & $2.7 \mathrm{~cm}$ & $4.7 \mathrm{~cm}$ \\
\hline 21 & $\begin{array}{l}\text { Length of rud. stigma and } \\
\text { style }\end{array}$ & $4.1 \mathrm{~cm}$ & $2.7 \mathrm{~cm}$ & $4.7 \mathrm{~cm}$ \\
\hline 22 & Pollen fertility & $72.13 \%$ & $98.69 \%$ & $43.7 \%$ \\
\hline 23 & Pollen size (diameter) & $0.13 \mathrm{~mm}$ & $0.1 \mathrm{~mm}$ & $0.12 \mathrm{~mm}$ \\
\hline
\end{tabular}

Cytology: Musa acuminata and $M$. rubra are diploid having $2 \mathrm{n}=22$ chromosomes. However, majority of the hybrids obtained from the cross have $2 n=33$ chromosomes. Meiosis in $M$. acuminata is characterized by the presence of high frequency of bivalents, unequal distribution of chromosomes and presence of laggards at anaphase I (Tables 2, 3). In $M$. rubra also, at metaphase I, high frequency of bivalents was observed, apart from this about $86 \%$ pollen mother cells showed presence of $1-3 \mathrm{~B}$ chromosomes which paired among themselves and separated equally to the two poles. Pollen fertility was $98.6 \%$ (Tables 2,3 ). The triploid hybrids of $M$. acuminata $\times M$. rubra have $2 \mathrm{n}=33$ chromosomes (Fig. 8). At meiotic metaphase I high frequency of bivalents followed by univalents and trivalents was observed (Figs. 4, 5). Five univalents were very commonly observed (Fig. 6). At anaphase I, 1-5 lagging bivalents were seen (Fig. 7) and chromosomes separated irregularly to the two poles 
(Tables 2, 3). At anaphase II equal number of chromosomes moved to two poles (Fig. 9). Stickiness of chromosomes was observed at metaphase I. Pollen fertility was $43.70 \%$.

\section{Discussion}

The two species Musa acuminata and $M$. rubra have striking differences in their growth habit, inflorescence orientation and leaf shape. Baker (1893) has placed $M$. acuminata in subgenus Eumusa of Musa and $M$. rubra under sub-genus Rhodochlamys on the basis of number of flowers to a bract and bract colour. Morphologically, triploid hybrids are more like $M$. acuminata rather than $M$. rubra. The occurrence of triploids in the cross of these diploid species suggests formation of unreduced female gametes in $M$. acuminata (since $M$. rubra invariably produces haploid pollen grains) which on fertilization with normal haploid male

Table 2. Table showing chromosomal associations in PMCs of Musa acuminata, M. rubra and their hybrid

\begin{tabular}{lcccc}
\hline \hline Musa species/hybrid & $\begin{array}{c}2 \mathrm{n} \\
\text { chr. no. }\end{array}$ & $\begin{array}{c}\text { Univalents } \\
\text { per PMC }\end{array}$ & $\begin{array}{c}\text { Bivalents } \\
\text { per PMC }\end{array}$ & $\begin{array}{c}\text { Trivalents } \\
\text { per PMC }\end{array}$ \\
\hline Musa acuminata* & 22 & 3.67 & 9.17 & - \\
M. rubra** & 22 & 0.2 & 10.21 & 0.46 \\
M. acuminata $\times$ M. rubra $(3 \mathrm{n})$ & 33 & 5.0 & 11.00 & 2.00 \\
\hline
\end{tabular}

* Agarwal 1988.

** Agarwal 1983.

Table 3. PMCs showing chromosomal distribution at anaphase $\mathrm{I}$ in $M$. acuminata, $M$. rubra and their hybrid

\begin{tabular}{|c|c|c|c|c|c|c|c|c|c|c|}
\hline \multirow{3}{*}{$\begin{array}{c}\text { Musa species/ } \\
\text { hybrid }\end{array}$} & \multirow{2}{*}{\multicolumn{7}{|c|}{ Chromosome distribution at anaphase I }} & \multicolumn{2}{|c|}{ Laggards/PMC } & \multirow{3}{*}{$\begin{array}{l}\text { Pollen } \\
\text { fertility }\end{array}$} \\
\hline & & & & & & & & Range & & \\
\hline & $7-15$ & $9-13$ & $10-12$ & $11-11$ & $15-18$ & $16-17$ & Others & 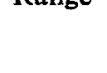 & $\begin{array}{l}\text { showing } \\
\text { laggards }\end{array}$ & \\
\hline M. acuminata* & 7.7 & 7.7 & 7.7 & 30.77 & & & 46.15 & $0-4$ & 46.15 & $72.13 \%$ \\
\hline M. rubra** & & & & 98.00 & & & 2.00 & $0-2$ & 86.00 & $98.69 \%$ \\
\hline $\begin{array}{l}\text { M. acuminata } \times \\
\text { M. rubra }(3 \mathrm{n})\end{array}$ & & & & & 9.00 & 18.00 & 73.00 & $0-8$ & 72.72 & $43.70 \%$ \\
\hline
\end{tabular}

* Agarwal 1988.

** Agarwal 1983.

gametes from $M$. rubra produce triploid $(2 \mathrm{n}=33)$ hybrids. This is further confirmed by the dominance of $M$. acuminata characters in the hybrid. The phenomenon of restitution nuclei formation has played an important role in the evolution of present day triploid (AAB and ABB) bananas, which are considererd to have evolved by hybridization of restitution nuclei forming cultivars of $M$. acuminata with $M$. balbisiana pollen and vice versa (Simmonds 1966). This phenomenon of unreduced female gamete formation has also been made use of, in breeding improved triploid and tetraploid banana varieties (Row and Richardson 1975). Meiotic studies in the PMCs of Musa acuminata did not reveal the formation of unreduced male gametes (Agarwal, 1988) indicating thereby that meiosis leading to the formation of male gametes do not necessarily reflect the events taking place during formation of female gametes. Similar observations on variation in male and female meiotic divisions have been made by Darlington and LaCour (1940) in Lilium. They, however, considered it to be due to differences in living space available for the chromosomes. 
The presence of eleven bivalents at metaphase I in the PMCs of triploid hybrids apparently suggests the complete bivalent formation of $M$. acuminata chromosomes and their non homology with $M$. rubra chromosomes. Attempts are underway to obtain diploid hybrids of $M$. acuminata $\times M$. rubra, the pairing behaviour of chromosomes in this will further throw light on species relationship. The restitution nuclei forming clone of $M$. acuminata, identified during the present hybridization programme, however, cannot be used for breeding purposes as it lacks the desirable fruit characters and quality necessary for incorporation in the improved hybrid.

\section{Summary}

Cytomorphology of interspecific hybrids of Musa acuminata $\times M$. rubra showed $2 \mathrm{n}=33$ chromosomes. The hybrid had intermediate morphological characters. The occurrence of triploids in diploid $\times$ diploid cross suggested formation of unreduced female gametes in $M$. acuminata. The absence of unreduced male gamete formation in the same indicated differences in male and female gametogenesis in same species. Formation of 11 bivalents per PMC in hybrids apparently suggests complete pairing of all $M$. acuminata chromosomes and lack of homology with $M$. rubra chromosomes.

\section{Acknowledgements}

The author is thankful to Director, Indian Institue of Horticultural Research (ICAR), Bangalore for providing necessary facilities to carry out the work.

\section{References}

Agarwal, P. K. 1983. Karyotype and B-chromosomes of Musa rubra Wall. Cytologia 48: 275-280.

- 1988. Cytogenetical investigations in Musaceae. III. Meiotic studies in diploid Musa species and banana varieties of India. Cytologia, 53: 359-363.

Baker, J. G. 1893. A synopsis of the genera and species of Museae. Ann. Bot. 7: 189-222.

Bernardo, F. A. 1957. Plant characters, fibre and cytology of Musa balbisiana $\times$ Musa textilis $F_{1}$ hybrids. Philipp. Agriculturist 41 : 117-156.

Darlington, C. D. and La Cour L. 1940. The causal sequence of meiosis III. The effect of hybridity on male and female cells in Lilium. J. Genet. 41 : 49-64.

Row, P. R. and Richardson, D. L. 1975. Breeding bananas for disease resistance, fruit quality and yield. Bull. Trop. Agric. Res. Serv. La lima Honduras pp. 41.

Simmonds, N. W. 1966. Bananas. Longman Green. London. 